\title{
Countering war or embracing peace? Dialogues between regionalism and multilateralism in Latin America (1945-1954)
}

\author{
Alexandre L. Moreli Rocha ${ }^{1}$ and Boris Le Chaffotec ${ }^{2}$ \\ 1 Center for International Relations,Fundação Getulio Vargas, Brasil \\ 2 UMR IRICE, Universités Paris 1 - Paris 4 - CNRS, Paris, France \\ e-mail: alexandre.moreli@fgv.br, boris.lechaffotec@hotmail.fr
}

Submitted: 10 September 2014. Accepted: 15 February 2015

\begin{abstract}
Still an open debate, definitions about the beginning of the Cold War were even more ambiguous to actors at the time concerned with development and exit strategies for the Second World War. That was precisely the scenario to several Latin American leaders who, far from the Iron Curtain, were debating the rise of the UN system and of parliamentary diplomacy. Focusing on a multilateral strategy of action for the post-war international order, our work tries to put together the Pan-Latin, Pan-American and UN policies of Latin Americans since the Chapultepec Conference of February 1945 until the 1954 Conferences of Caracas, which fashioned the Organization of American States' Cold War status, and of Madrid, which failed to consolidate the Latin Union.
\end{abstract}

KEYWORDS: International history; latin America; transatlantic relations; latin union; organization of american states; united nations; cold war

Citation / Cómo citar este artículo: Alexandre L. Moreli Rocha and Boris Le Chaffotec (2015). "Countering war or embracing peace? Dialogues between regionalism and multilateralism in Latin America (1945-1954)". Culture \& History Digital Journal, 4 (1): e002. doi: http://dx.doi.org/10.3989/chdj.2015.002

RESUMEN: ¿Luchar contra la guerra o abrazar la paz? Diálogos entre regionalismo y multilateralismo en América Latina (1945-1954).- Todavía un debate en abierto en la historiografía, la definición sobre los marcos del principio de la Guerra Fría fue aún más ambigua para los actores involucrados en el conflicto bélico precedente y preocupados con el desarrollo y las salidas estratégicas posibles de la Segunda Guerra Mundial. Esta fue la realidad para varios líderes latinoamericanos que, lejos de la Cortina de Hierro, quedaban mucho más preocupados con el surgimiento del sistema de las Naciones Unidas y la diplomacia parlamentaria. Centrándose sobre las estrategias multilaterales para la orden internacional de la posguerra, nuestro trabajo pretende analizar las políticas Pan-Latinas, Pan Americanas y para las Naciones Unidas de la América Latina desde la Conferencia de Chapultepec, en febrero de 1945, hasta las Conferencias de 1954 de Caracas, que consolidó la Organización de los Estados Americanos en un contexto de Guerra Fría, y de Madrid, que no logró consolidar la Unión Latina.

PALABRAS CLAVE: Historia internacional; América latina; relaciones transatlánticas; unión latina; organización de los estados americanos; naciones unidas; guerra fría

Copyright: (C) 2015 CSIC This is an open-access article distributed under the terms of the Creative Commons AttributionNon Commercial (by-nc) Spain 3.0 License.

Besides the work with the regional history itself, discussing Latin America's specificities during the Cold War allows scholars not only to put aside the narrative arising from the structuralist approach that was formed during the events, ${ }^{1}$ but also to answer to different issues that originate when longer periods of time are taken into consideration in the historical investigation (Westad, 2010: 2, 7,8 ). The bipolar representation of the second half of the twentieth century, which is useful in a preliminary approach, should be revised in order to better understand 
the complexity of particular — regional or nationalmechanisms already explored in studies about the "Third World"2 or the construction of Europe. ${ }^{3}$

Taking into account this perspective, we intent to apprehend and question Latin American position and the consistency of its cohesion as a group while great powers were adopting a Cold War rationale after the Second World War. The main argument here is that, despite renewing an old national anti-communism and before supporting Washington in a Global Cold War, the region ventured a different and much more autonomous international outreach for almost ten years. For that purpose, it seemed interesting to take into consideration initiatives from this new international scene that were not conditioned either by the so called new "bipolar" conflict or by any regional autochthone identity. Even if these opportunities vanished during the 1950's, the structural condition for their emergence remained latent during the Cold War enabling phenomena like the Third World or, more recently, the BRICS countries.

Still an open debate, definitions about the beginning of the Cold War were even more ambiguous to actors at the time concerned with development and exit strategies from war. Actually far from representing a clear rupture as those seen at the beginning of classic military conflicts, this "bellicose peace", to quote Raymond Aron (Aron, 1962: 17), should be understood as only an additional form of political rivalry during the consolidation of a new post-war international order. That was precisely how several Latin American leaders were defining the circumstances. Far from the Iron Curtain, they were highlighting the rise of the UN system and of parliamentary diplomacy, understood as the multilateral international organizations working like national parliaments and giving each representative - in this case, nations - a vote (Kennedy, 2006). Before becoming a stage for rivalries between Moscow and Washington, the promises for the multilateral organization seemed substantial and real to potential members.

Considering this post-war international scenario, this paper tries to put for the first time in perspective and in relation the Pan-American, the Pan-Latin and the UN policies of Latin Americans. The main objective is to analyze these dynamics from Chapultepec Conference, in February 1945, until the 1954 Conferences of Caracas, which fashioned the Organization of American States (OAS)' Cold War status, and of Madrid, which failed to consolidate the Latin Union (LU).

Our study will also take into consideration important events for this narrative such as the signing of the Rio Treaty of September 1947, establishing the Inter-American Reciprocal Assistance agreement, the Conference of Bogotá of April 1948, forming the OAS, and the creation of the LU in June 1948, whose aim was to associate the Latin $^{4}$ countries in Europe with their confreres in the Americas. Moreover, we will confront the Latin American interests with those of the United States and France, especially the ones related to the emerging double institutional initiative OAS-LU while new power struggles arose in international order. By avoiding a mere factual analysis of what the OAS or the LU represented, we aim to better understand the articulation between their respective calendars and how they evolved institutionally as the Cold War became global and diminished the UN influence.

Historiography frequently emphasizes Latin America's relationship with the United States or with the Western Bloc during the Cold War, and hardly proposes a global perspective covering the connections (or their absence) between the bipolar conflict and the region. As a result, it is no surprise that the LU has rarely received attention. ${ }^{5}$ Moreover, despite recent efforts from Global History (Harmer and Riquelme Segovia, 2014 and Harmer, 2014), from works discussing the origins of the United Nations Organization (Pernet, 2014) or the Multilateral Trade System (Farias, 2014) to take into account Latin American perspectives, approaches surpassing a Latin American identity or the North-South polarization remain rare. Actually, even studies on the OAS are still extraordinary and frequently limited to juridical aspects or to specific dossiers such as the U.S. intervention in Guatemala, the Cuban crisis or the defense of Human Rights. ${ }^{6}$

Our approach will actually give preference to regional interests when trying to retrace policies that can be recognized as Latin Americans, even if certain national particularisms appear as inescapable to the historian's scrutiny for this period. At the same time, even if we do not intend to consider the region as a cohesive and single whole, the formal limits of this text do not allow an exhaustive examination of different national policies, which, as a matter of fact, received already fascinating investigation by several researchers. The studies led by Leslie Bethel and Ian Roxborough (Bethell and Roxborough, 1992), for instance, were developed contemplating this post-war context, even if dealing marginally with international issues.

Part of a more wide-ranging study developed by the authors, this analysis will mainly focus on ideas and diplomatic negotiations between Latin America and its partners in the U.S. and in Europe and, more especially, on United States' and France's interests related to the OAS and the LU.

\section{FOR A LATIN AMERICAN VOICE IN THE POST-WAR WORLD}

Even if the creation of an Allied front in the Americas cannot be ignored when analyzing post-war planning in the region, the events related to the Latin American engagement in the war are far from representing a historical rupture. Actually, traditional debates were resumed or remodeled due to the conflict. While Pan-American initiatives since the end of the ninetieth century had been favored not only by the Washington's but also by the Latin Americans' economic interests, the new United States war effort ended up relying on natural resources and production from the south of the continent. 
Moreover, beyond the political and moral values of the Atlantic Charter, which meant the fight against Nazi fascism and the defense of historical principles for the Americas like self-determination, the Conference of Rio de Janeiro in January 1942 was particularly facilitated by economic advantages and counterparts offered by Washington. And even if Argentina presented itself as an exception by not following its neighbors in a first moment, Buenos Aires finally associated itself to the Allies in 1945.

Despite being called outside the context of the PanAmerican Union, the Chapultepec Conference on warfare, between February and March 1945, went further than just discussing military issues. Considering exit strategies for the conflict and post-war planning, it eventually contemplated continental solidarity and the reinforcement of the inter-American system. Actually, once the difficulties related to the war alliances were overcame, the agenda focused on three issues: primarily, the challenges related to development and consolidation of regional institutions, secondly, the dealing with political issues, and thirdly, social and economic problems.

Far from representing a simple US initiative, the conference witnessed a strong commitment from several Latin American countries, especially the host, Mexico. Motivated by the conflict, the meeting ended up by resuming the regional cooperation process. As a result, the Act of Chapultepec, approved unanimously by the participants, recommended the adoption of a reciprocal assistance and solidarity treaty in order to create effective institutional mechanisms within the Pan-American system. At the same time, while looking forward to the next Inter-American Conference, expected to be held in Brazil the following year, delegates carefully discussed the reinforcement of already existent instances in the realms of politics, economy and social issues.

These new initiatives were accompanied by an apparent ideological reorientation when the Americas assumed the liberal aspirations embodied by the Atlantic Charter. In a moment in which war was not yet over, Latin America sought a better position in a rising international system whose boundaries were defined without its presence during the 1944 Dumbarton Oaks Conference held by the United States, United Kingdom, USSR and China.

Indeed, Chapultepec ended up revealing the Latin American concerns about the post-war situation, especially regarding its role in the new international order. In this sense, decisions from Dumbarton Oaks were constantly contested and the place of the hemisphere within the ambitioned new League of Nations was questioned. The U.S. Secretary of State, Edward Stettinius, feeling the tension among the delegations, finally invited the states of the New World to take part in the discussion about the construction of the new international system in the forthcoming San Francisco Conference. ${ }^{8}$ Despite the enthusiasm provoked, the invitation did not dissipate the doubts concerning sovereignty and autonomy for the hemisphere within the future organization. That was one the main reasons why Latin Americas kept alive their interest in resuming the process of regional cooperation.

Signed on June 26th 1945, the United Nations Charter only partially attenuated those fears. Despite putting an oligarchic Security Council next to a General Assembly relying on one vote per State, the tendency of the first overshadowing the second was quickly noted. Only a scenario where the Assembly had more power could reassure Latin America due to its considerably larger numerical presence there. Since the European Empire's colonies were not part of the Organization at that point, from the 51 UN Members in 1945, 20 were Latin Americans, the largest regional group inside the organization.

Without a permanent place in the Security Council, the region questioned if it still would have the final world when its own regional problems were to be discussed within the new security system (Campbell and Herring, 1975: 275, 184). This had been a crucial issue at Chapultepec ${ }^{9}$ but also during the following years. At the Paris Peace Conferences of 1946, for instance, the Brazilian Minister of Foreign Affairs, João Neves da Fontoura, would ask for a "Latin front" in the international system against the control of decision-making by the Four Powers. ${ }^{10}$

The fear of isolation grew even more as the end of the war and Europe's reconstruction reduced economic help and political support from the United States. The Truman Doctrine, followed by a plan for European reconstruction by Secretary of State George Marshall, would be the main milestones of the apparent abandonment of the hemisphere by Washington. ${ }^{11}$ Not surprisingly, these issues were in the Latin American thoughts during the following regional Conferences of Petrópolis and Bogotá.

While Mexico, for instance, ended up requiring a stronger continental economic cooperation within a classic liberal perspective, $\mathrm{Cuba}^{12}$ and above all Argentina ${ }^{13}$ decided to use Truman Doctrine's own logic to request for a resumption of U.S. help to the region. The communist threat represented then much more a Latin American rhetorical weapon in their economic, financial and military relationships with the United States than an immediate Cold War issue.

Meanwhile, the appropriation by some actors, such as part of the Brazilian ruling elite, of the project for a Latin Union of Nations at the same time that OAS emerged was a sign of how important regional organizations became. Proposed in France, within a developing Latin Americanism context intending to put Paris in a place of prominence in the Americas, the LU was perceived by the other side of the Atlantic as a political maneuver with great potential and capable of propitiating, through a cultural vector called latinidade, a close collaboration with a key country in the new political and international security system.

Even if the association was eminently symbolic, it seemed able to become a powerful instrument for international politics by offering its members, if united, a consider- 
able importance in the UN General Assembly ${ }^{14}$ and a veto in the Security Council. Besides being a clever maneuver for the French, the LU also represented a mean for Latin America to avoid being marginalized by the new contradictions the international system started to experience.

Beyond impacting bilateral relations between the States concerned, the UN system and the aspirations for a OAS and a LU ended up implicated in a tense trilateral relationship since the very moment war was over. ${ }^{15}$

\section{8: UNITE TO EXIST}

The sequence to Chapultepec, initially foreseen for November 1946 in Petrópolis, in the mountain region of Rio de Janeiro, was postponed several times while regional disputes resurged between the supporters of Perón's Argentina and its detractors led by the United States. Only in mid-1947, after Buenos Aires had finally recognized the decisions taken at Mexico, Washington agreed to take part of new discussions on continental peace and security. The talks were then scheduled to August and September.

While the meeting's agenda only foresaw debates on how to enforce the Act of Chapultepec, the announcement of the Marshall Plan a few weeks before caused a great mobilization among the Latin American States. Their ambition then became to extend that promises to their region. During the opening ceremony, for instance, the Mexican Minister of Foreign Affairs Jaime Torres Bodet reminded that the peace could not reign in the continent without a closer economic cooperation. ${ }^{16}$

While Bodet presented a draft resolution in this sense that was supported by Peru and Argentina, Marshall was able to skillfully control discussions and to postpone further deliberation on the topic. ${ }^{17}$ Despite the thematic rupture and the consequent adjournment of debates about Mexican demands, the strong Latin American support to Washington was almost not affected, a clear demonstration of U.S. strength at the time. Finally, the Inter-American Treaty of Reciprocal Assistance (TIAR) signed at Petrópolis preserved the key approaches intended by the US since the beginning, such as: the need for two thirds of the participants for voting, national freedom regarding the means to be made available in the case of collective actions, pacific resolution of controversies, and the creation of mechanisms for discussion of issues related to intra or extra continental threats. Far from being a mere passive consent, as Moscow seemed to accuse, ${ }^{18}$ the decision for that form of association could be better explained by Latin American States' desire to avoid international isolation and, above all, to circumvent the high economic and military costs that could arise from that hypothetical insular position. ${ }^{19}$

Considering that conjuncture, it is hard to sustain the creation of the regional bloc as deriving from rationalities essentially connected to the Cold War which, as a matter of fact, was still incipient at that very moment. In 1947, the TIAR seemed actually to redress the Monroe Doctrine and to finally materialize several aspirations regarding continental solidarity present in the Pan-American Union context since 1890 .

If the fears regarding leftist radicalisms were indeed around the Conference's hallways, the Treaty itself did not established an anticommunist alliance and even less an anti-soviet one. The United States were still following the post-war planning strategy of appeasement and did work so the Conference would not take a different tone. Yet upholding the reconciliation process between the Western hemisphere and the USSR started in $1945,{ }^{20}$ Marshall discarded several Latin American draft resolutions considered anti-communist, especially those from Argentina, in order not to increase the distrust between the two super powers. ${ }^{21}$ The fight against the fifth column, despite being a real concern, was discarded for the moment.

While accomplishments were celebrated, the resolution of a great number of issues ended up postponed to a new meeting at Bogotá the following year. Besides economic concerns and the fight against communism, it remained also opened for discussion the foundation of an organization that could embrace the compromises approved in Petrópolis. In such a context, the Ninth InterAmerican Conference became a major Summit as it totally refunded the Pan-American system. Intense discussions were held from the very first talks, on March 30th, until its conclusion, on May 2nd, 1948.

The aims included not just the search for a more rational, neighboring and efficient Inter-American system, but also the foundation of an organization which could accommodate different interests. While Mexico reassumed the leadership regarding the discussion of economic problems, the United States concentrated their efforts in founding effective means for security and military cooperation. If both expectations had been honored, a renewed and solid institutionalization would have allowed a strong regional unity within the international order while economic agreements would have consolidated the relations between the member states. That was not, however, what happened in the following years. ${ }^{22}$

The proclamation of democratic and liberal principles during the Conference ended up indirectly, but effectively, creating antagonism to communism. If the United States were able to avoid the issue until then, the multiplication of Latin American initiatives made mandatory discussions on a Pan-American agreement on the matter. ${ }^{23}$ However, far from wanting to compromise itself in a regional agreement against communism, ${ }^{24}$ Washington tried to avoid taking a stand.

In association with Brazil, Chile and Peru, the United States presented a simple declaration of principles instead of a draft for a binding resolution. They claimed not just to favor the preservation of democracy against possible totalitarian detours arising from communism, but also, and this is worthy of notice, from rightist authoritarian regimes. ${ }^{25}$ Approved by Argentina, Costa Rica, Honduras, Nicaragua, Panama, Paraguay, Bolivia, Ecuador, Mexico, Uruguay and Venezuela, this document (number 32) in favor of The Preservation and De- 
fense of Democracy in America ended up accompanying the Final Act of Bogota, which created the Organization of American States.

Even if an anti-communist architecture was rejected for the moment, the decisions left to each country, as a national affair, the task of dealing with whatever they understood as threats to democracy. Therefore, as the OAS held the same post-war strategy imagined at the end of World War II, alongside western democracies, ${ }^{26}$ it was not yet part of President Truman's containment.

The UN General Assembly and the OAS constituted the only two political forums with international weight where Latin America was included at the time. Many topics of the regional agenda, however, remained uncovered. In that context, and only a few weeks after the Conference of Bogotá, an Administrative Act of June 14th 1948 by the French Ministry of Justice ended up authorizing the creation of a "foreign association called Latin Union". ${ }^{27}$ The "golden age" of Latin-Americanism in France ${ }^{28}$ finally presented an alternative to the institutional development and the efforts of rapprochement between the North and South Americas. Beyond its natural interest as a great power, the French government was aware of the Pan-American concerns regarding Europe and its colonial presence in the American continent. The early years of the French Fourth Republic coincided with a major shift for the country's Foreign Policy. The neutralist "Third Way" strategy formerly built by General De Gaulle had to be revisited due to the failure of the Moscow Conference of 1947 and the Soviet rejection of the Marshall Plan. It was in this new context, where the German question and the French Union remained central, that Latin America seems to have gained a new importance (Grosser, 1989: 19-79).

At the time, considering the political and military obligations involved, to take part as a full member of an emerging Inter-American system seemed not only implausible but also highly costly for France. ${ }^{29}$ These were some of the reasons why the French lawyer Pierre Cabanes, special assistant (Chargé de Mission) to the President of the French Council of Ministers, proposed a movement to unite the so called "Latin" countries (Europeans and Americans) around France. ${ }^{30}$

Besides fitting on the French international agenda, the Latin Union closely followed the OAS' institutional evolution. By offering new opportunities in international order to its participants, it actually became an alternative to the Inter-American system.

French leadership in 1948 was facilitated by the momentary Brazilian contempt regarding a "Latin front." 31 President Dutra had actually replaced his Minister of Foreign Affairs, considered the "spiritual father" of the LU, at the end 1946. Fontoura's substitute, Raul Fernandes, a diplomat hostile to the project and a much stronger anticommunist than his predecessor, favored the institutional evolution of the inter-American system aligned with the United States. $^{32}$

Therefore, an "international" institution aiming to "facilitate the cultural, economic and social relations among individuals and the collectivity of Latin countries" was finally and unilaterally created by Paris. ${ }^{33}$ Cabanes, nevertheless, did not dissimulate his inspiration had come from Fontoura's wish to "create a Latin Front with the purpose of defending the common aspirations and interests of Latin people in International Conferences." 34 Also, talking to the press right after the launching of the LU initiative, the French presented the organization as opposing the OAS. For him, "the Latin Union relie[d] on the race and civilization affinities that $\mathrm{d}[\mathrm{id}]$ not exist in the PanAmerican movement." 35

The project was ambitious and clearly permeated by French interest in preserving some influence over Latin America. Moreover, by demanding an "inter-Latin" coordination of insurance companies, of raw material's trade and of transatlantic transports, economic and financial issues seemed to deserve the very same attention than cultural aspects for the organization. ${ }^{36}$

Cabanes did not take long to visit Latin America. His first aim was to inaugurate LU national committees and to set the bases for its first international conference. ${ }^{37}$ However, his errors and misunderstandings of local aspirations when presenting the UL to Latin-Americans would cost him a lot. By using a vague discourse, by not explaining clearly enough what kind of new gains the LU could bring when opposed to the OAS, by not minding enough the regional concerns with communism and by being careless when choosing his local associates, he provoked not just opposition to the project but especially to the French leadership. His own fellow diplomats agreed he did so many mistakes he got to the point of discrediting a "fair and appealing" idea. ${ }^{38}$

Even if not in the Government, Fontoura assumed the responsibility of creating the LU Brazilian committee as soon as he heard about the French initiative. The Brazilian then identified another window of opportunity to put his country in the lead of a third force in international affairs. When questioned by the press if the LU would not be challenging decisions taken at Bogotá, Fontoura did not hesitate:

No. The Pan-American Union is for the Latin Union more than just parallelism: it is a bridge and an encouragement. Both unions, expressing themselves differently, are alike when defending peace but apart in the methods to reach that goal. The Organization of American States relies on the geographical neighborhood solidarity, and the Latin Union acts based on similarities and affinities arising from the same ethnic origin, the same spiritual base, and the same cultural source. (...) We will put together considerable forces within the Latin Union framework to vigilantly safeguard Law, International Justice and freedom..$^{39}$

Fontoura also remembered the ideas that had emerged when Brazilian post-war planning was being considered in 1944. Yet that time he reaffirmed to believe that "Pan-Americanism represented an armor to the defense of Americas and to the reinforcement of the economic and cultural relations among the New World 
nations, but its practice must not imply isolationism visà-vis other countries." 40

After he had confronted his first difficulties south of the Equador, Cabanes reacted by approaching the European "Latins" in order to have at least Madrid, Lisbon and Rome together with Paris. Moreover, his speeches then started to focus on the potential to create "a regional group in the spiritual level capable of great influence in the difficult process of guaranteeing peace within international organizations." ${ }^{41}$ If prospects for such initiative were infinite, so were the chances of failure.

Even before their first important summit, scheduled for October 1951, harmony among members faded. But LU weakening was less caused by the evolution of the anti-communist rhetoric than by the internal contradictions among its members, by the launching of the European integration process and by the marginalization of Latin America when the so called "Third World" emerged on the other side of the planet.

\section{NEW CHALLENGES AND CONTINENTAL POLARIZATION}

In a region where susceptibilities have always been eminent and where particularisms seemed to always challenge the affirmation of a Latin American identity, one of the few constants among the more than twenty Latin nations has been their relationships with the United States. In a many times suitable, others tense, relationship with the south of the Americas, the US had been consolidating since early twentieth century what would later constitute a typical Cold War milestone: a system of domination by a great power over its immediate neighborhood (Westad, 2005: 84, 97,143).

Taking into consideration U.S. interventions and regional political conflicts existing since the Mexican Revolution, the historian Gilbert Joseph considers that Latin America had already lived its own Cold War far before 1945 (Grandin and Joseph, 2010: 400-411). Even if avoiding using Joseph's argument of an early Cold War in the new continent (actually more suitable for Central American than for the rest of the region), it is still possible to state that, from the mid-1940s to the mid-1950s, the region had just experienced the resumption of debates on old problems related to its economic development, to the strengthening of the State and to its international role (Cervo, 2007: 9-30).

The complexity of the Soviet issue and the lack of an explicit ideological plan of defense for the continent in Chapultepec, Petrópolis and Bogotá, together with the LU project, show that the region sought a unique and more autonomous role for the new international order while its old anticommunist feeling submerged and diluted itself in the polarization of the national political scene (Joseph, 2008: 20). Thus, if there was aversion to the USSR, it was not more significant than "distrust regarding Europe" $" 42$ or strong reservations regarding the detour of the U.S. capital flow towards the Old Continent. As mentioned before, the aim here is to understand the evo- lution of different political initiatives affecting Latin Americans while avoiding to read the facts automatically through a uniform "global" Cold War framework.

Even if most part of the historiography sees the region's democratic phase between the end of World War II and the immediate post-war as being extremely damaged from 1948 on (Bethell and Roxborough, 1992: 1-32), on the other hand, its Foreign Policy towards the emerging Eastern Bloc would still take years to change. ${ }^{43}$ Even those sustaining that Latin Americans saw in Pan-Americanism a mean of fighting against communism must remember that was, above all, a regional and not a global issue. $^{44}$

The bipolar conflict actually affected Latin America as well as other marginal areas around the axis US-Eurasia. It did so, however, through a number of particularities and temporalities of its own, especially during the 1950s. This bring us back to the main argument sustained here, that before Cold War played a major role in the region, not only the OAS but also the LU were testimonies of a different post-war order from that emerging in Europe or Asia.

Developing itself faster than the LU, dynamics first started to change within the OAS' framework. The organization shifted its position within the global Cold War beginning with the Korean conflict until the Conference of Caracas of 1954. It was mainly through the U.S. diplomatic action that the TIAR and the OAS became new weapons for cold warriors. ${ }^{45}$ Actually, Marshal's leaving the head of the Department of State in January 1949 was one of the first signs of change. Dean Acheson, one of the main inspirations for the Truman Doctrine, got the post halfway through the Berlin blockage and became one of the main figures of the containment. Even if the priorities were Europe and Asia, he deeply reoriented the United States regional politics.

Truman's new policy emerged when U.S. diplomats worked for a closer relationship between the hemisphere and the anti-Soviet bloc during the IV Meeting of Consultation of Ministers of Foreign Affairs in 1951, when Korean War and communism were discussed. Even though several States refused to use TIAR to intervene in Asia, ${ }^{46}$ communism in the continent was clearly identified as a foreign threat. However, besides reaffirming cooperation regarding the fight against foreign threats, decisions arising from the meeting did not deepen the discussion yet.

Only after Eisenhower's inauguration the situation clearly changed, with the National Security Council considerably engaging in discussions about hemispheric politics (Rabe, 1988: 248). The NSC-144, a new orientation in managing regional issues, recommended an increase of aid to development in order to stop pro-communist movements and also to better integrate the OAS into the US Foreign Policy. In this sense, U.S. administration started to develop since 1953 an anti-communist proposition that would became one of the most important topics of the $10^{\text {th }}$ Inter-American Conference's agenda in Caracas in March $1954 .{ }^{47}$ 
Still not minding the complexity of Latin American's claims, especially regarding development, the United States gave the new proposition the maximum priority during the discussions. Aiming directly at the Guatemala situation, the Declaration of Solidarity for the Preservation of the Political Integrity of the American States Against International Communist Intervention was adopted regardless of Mexico's and Argentina's abstentions and the opposition from the Guatemalan delegation. Throughout this document, the OAS made a clear step into the global Cold War and became part of Eisenhower's Rollback policy.

LU followed a different pace. Since late 1949 and during the arrangements for its first Summit, scheduled for October 1951 at Rio de Janeiro, Cabanes started to defend a "mediator" role for the Organization in a world "divided between two great antagonistic powers". For him, not only the USSR but also the US pursuit misplaced models of modernity which gave "the 3000-year-old [Latin] civilization" a great responsibility as an alternative option. In that scenario, the LU's international outreach would mean much more than just choosing (or not) sides in Cold War; it could actually become a third pole able to operate a "great influence" in the United Nations system. ${ }^{48}$

The French initiative, however, suffered a blow. New interests emerged when other Latins started to seek breaks for international recognition and when Fontoura appeared again at the head of the Brazilian Ministry of Foreign Affairs. ${ }^{49}$ Believing Washington had turned its back to the region (Bandeira, 1978: 326), the Brazilian made a move not only to resume the LU project, but also to make Rio its leader. The plan, with no surprise, aimed to reduce France's and Cabane's prominence. ${ }^{50}$

In March 1950, Fontoura published a militant article in the same newspaper he had launched the idea of a "Latin front" in 1946. Without directly attacking communism, he presented LU as a mean of defending the Western Civilization, but also as a regional initiative compatible with the United Nations system. ${ }^{51}$ Since the first session of the UN General Assembly, Fontoura was aware of the potential of a Latin American group in the game of UN forces and also to counterbalance the power of the United States (Fontoura, 1963: 8-9).

Even if literal accusation against the USSR was not in the agenda for the first UL Summit, concerns such as to consider the "dangers that threatened the Western civilization" indicated that the global context was becoming inseparable from Latin worries. Yet, the main goal persisted. Resources were still directed to "study the practical means in order to include the different opinions coming from the Latin Union into the United Nations activities" and, for such, a "regional entente" was to be created. ${ }^{52}$

With the 1951 UL Summit approaching, the French Ambassador in Rio strongly urged Paris not to ignore the event. He pled for a distinguished delegation in other to avoid eventual "political maneuvers." ${ }_{53}$ Besides the Brazilian ambitions, there was also the risk that Madrid or
Buenos Aires would try to seize the organization's leadership. ${ }^{54}$ Proceeding accordingly to the Ambassador request, Edgar Faure, a distinct politician and then Ministry of Justice, led the French group.

Twenty-six Latin countries ${ }^{55}$ finally gathered for the first time in Rio de Janeiro between October 14th and 19th 1951. A tense environment confirmed expectations and, instead of being the proof of LU's strength, the meeting announced a fiasco.

In his opening speech, Fontoura focused on the exceptionalism of the "Latin Civilization" and on the Union's goal of "taking a position" before the UN and the OAS. Since the Cold War rhetoric did not monopolize the speeches (there was only one brief critical comment about "communist totalitarianism") (Centro de História e Documentação Diplomática, 2002: 25-26), national aims received all attention. Supported by a Spanish delegation eager for international recognition, Brazil guided the debates in order to marginalize Paris and Cabanes through the creation of a new Charter for the LU. ${ }^{56}$

According to a report by the French secret service, Brazil and Spain, each one defending its own interests, came together "to ambush" other delegations, especially the French, in order to "defeat the anti-Francoist government of Paris." ${ }^{57}$ Still according to the French, the goal in Rio was to "transform the Latin Union in a political organization parallel to the UN" so the Brazilian President Getulio Vargas could contain the US and place Brazil as the head of a "third locus of power" in a bipolar international order. ${ }^{58}$ If the French delegation was able to avoid the worst by temporarily keeping the LU headquarters in Paris and postponing a final decision about the new Charter, Brazil ended up electing one of its diplomats as Chair replacing Cabanes. ${ }^{59}$ Also, Madrid guaranteed the responsibility for hosting the next meeting, what Franco's regime extensively exploited in its propaganda. ${ }^{60}$

Amid contradictory debates and pointing towards a clear rivalry among the delegations, the motions adopted during the Conference were not able to surpass triviality or obscurity ${ }^{61}$ Therefore, the so desired "entente" was not possible.

If Fontoura had imagined to launch the project for a second time, he would soon experience a growing opposition from the own Brazilian press in additional to accusations of a "Francoist deviation" made by a marginalized Cabanes. ${ }^{62}$ Leaving his post in the Ministry in June 1953 due to disagreements with Vargas, Fontoura would even not go the next and last LU meeting (Fontoura, 1963: 175).

Everything represented a fatal blow to the organization which also agonized with the OAS alignment with Washington's containment (and later rollback), the France focusing its efforts in Europe and choosing different means of action in Latin America ${ }^{63}$ and, finally, the Portugal and Spain associating themselves to the Western Bloc through agreements signed with the US between 1949 and 1953 (Redondo, 1996: 212; Rollo, 1994: 235-292; Telo, 1996: 113-134; Viñas, 2003: 198).

LU's second Summit in Madrid in 1954 definitively finished with the French leadership when its new Charter 
was approved as an international but empty treaty (Congrès International de l'Union Latine, 1956: 53, 82-85, 145-159). The cultural aspect was actually the only one preserved over the political and economic ones (Congrès International de l'Union Latine, 1956: 51). Not even the vague request for a "gradual elimination of economic barriers existing between the Latin countries" previewed by the Brazilian draft was taken into consideration (Congrès International de l'Únion Latine, 1954b, 2, 27-49). By an astonishing coincidence, the debates were closed on May 15 th 1954 , the very same day the vessel Alfhem arrived in Guatemala bringing Czeck-Slovak weapons. The event would be exploited by Washington to justify a coup d'état a few weeks later, which brought to life the intentions previously announced in Caracas by the OAS Declaration of Solidarity and which started a new phase for the Cold War in the region.

While the LU would remain an empty idea until the end of the Cold War ${ }^{64}$ the OAS engaged deeply in the WestEast conflict, especially when dealing with the Cuban issue. Latin America then lost its chance to present (and become) an alternative to the bipolar system. An opportunity that others would be able to better seize at Bandung few months after the fall of Arbenz in Guatemala.

\section{NOTES}

1. Being here considerate, for instance, the theories developed by Hans Morgenthau (Morgenthau, 1948) or in the work of the diplomat and scholar George Kennan.

2. Numerous works on the non-aligned movement have been showing distinctly the limits of the bipolar analysis, such as those of Philippe Braillard (Braillard, 1987).

3. An interesting example was the conference "Europe and the End of the Cold War. A reappraisal" held in Paris in 2006 and organized by Frédéric Bozo, Marie-Pierre Rey, Piers Ludlow and Leopoldo Nuti, whose proceedings were published in 2008 (Bozo, Rey, Ludlow and Nuti, 2008).

4. The term latin (in italic) and its variants will be used here as an adjective to designate the group of countries involved with and the pretended interests related to the Latin Union project.

5. Among the rare works that approach the LU, deserve attention those from Jacques Chonchol and Guy Martinière (Chonchol and Martinière, 1985) and from Juan Carlos Redondo Jiménez (Redondo Jiménez, 1996).

6. Carlos Stoetzer remains one of the main scholars having worked with the topic (Stoetzer, 1993).

7. Suggested Agenda Approved by President Roosevelt for the Conference of the American Republics Collaborating in the War Effort de 18/01/45 (Foreign Relations of the United States (FRUS), 1945, vol. 9: 10).

8. Speech delivered on March 5 during the plenary session of the Conference (Department of State. Bulletin, 11/03/45: 395).

9. Immersed in a tense context, the writing of the final declaration ended up laying particular emphasis on the need for a regional alliance for the defense of the rights of American nations due to "the new situation in the world" (Act of Chapultepec, 03/03/45).

10. A.M. (1946) «La Diplomatie Mondiale à Paris. Un entretien avec M. Neves da Fontoura chef de la délégation brésilienne à la conférence de la paix qui travaille à la reconstitution d'un 'front latin'». Le Monde, $3^{\circ}$ ano, n. 525, 30/08/1946: 3.

11. Economic abandonment verified even by the Office of Financial and Development Policy of the Department of State in a memorandum of $19 / 02 / 48$. Truman would still try to convince Latin Americans in several opportunities his new foreign policy was fair as, for instance, during the closing session of the
Conference of Petrópolis in 02/09/47 (FRUS, 1948, vol. 9: 5-9).

12. See talks between George Marshall and Guillermo Belt, Cuban Ambassador, of 28/08/47 during the Petrópolis Conference (FRUS, 1947, vol. 8: 69-70).

13. See talks between George Marshall and Juan Bramuglia, Argentine Minister of Foreign Affairs, of 20/08/47 during the Petrópolis Conference (FRUS, 1947, vol. 8: 42-44).

14. The UL project aimed to put together 25 UN members, besides Switzerland.

15. Such tension becomes evident even on a superficial analysis of its constituent texts in a comparative basis. The preamble to the OAS Treaty, for instance, makes clear reference to the UN Charter and to its articles 52 and 53 on international organizations. Similarly, article 2 of the UL Charter of 14/06/48 links (sometimes tacitly opposing) its goals to those of the UN.

16. Marshall's report to the interim Secretary of State of 16/08/47 (FRUS, 1947, vol. 8: 35-36).

17. FRUS, 1947, vol. 8: 53-54.

18. FRUS, 1947, vol. 8: 85-86.

19. The leader of the Uruguayan delegation stated on $11 / 09 / 47$ that "Latin America has neither the will nor the means to form an independent association from the United States" (FRUS, 1947, vol 8: 82-83).

20. It must be noted that Washington had brokered negotiations for resumption of diplomatic relations between Moscow and LatinAmericans as Brazil, Bolivia, Guatemala and Peru (FRUS, 1945, vol. 9: 222-230).

21. The instructions of $29 / 05 / 47$ from the Department of State insisted that the US Delegation should seek to conclude "provisions which will adequately cover acts or threats of aggression executed through subversive activities, but which will not take the form of an alliance directed against the Soviet Union" (FRUS, 1947, vol. 8: 1-3).

22. The Economic Agreement reached at Bogota was only ratified by Costa Rica, Honduras and Panama after having been unanimously approved at the end of the Conference. The U.S. disdain largely explains the agreement's failure.

23. The two most important initiatives were the Argentine proposal and the joint proposition of Haiti and the Dominican Republic in favor of a clear regional agreement to fight communism (FRUS, 1948, vol. 9: 193-201).

24. On the Policy Planning Staff paper no. 26 of 22/03/48, which served as the basis for the U.S. delegation position on the issue, the communist threat is relativized and defined as a national problem, not regional. The document recommended that "The United States should not enter into anti-Communist agreement with the other American Republics, and should oppose a multilateral inter-American anti-Communist agreement, until further study has been given to the problem." (FRUS, 1948, vol. 9 p. 193-201).

25. This nuance was highlighted in the pronouncements of the Venezuelan delegation, but also in those of Marshall (ibidem). The relativity of the anticommunist matter in Inter-American issues was also stressed in the analysis of the French diplomacy on these events (French Ministry of Foreign Affairs Diplomatic Archives (FMFADA). Serie Nations Unies et Organisations Internationales 1944-1959, vol. 104. S.10.11. Memorandum of 08/09/47, the French Ambassador in Brazil, Hubert Guerin, to the Ministry. And French National Archives (FNA). Fonds d'origine privée. Fonds Georges Bidault. 457 AP, box 81 (Amérique Latine). Telegram n. 117-120 of 03/04/48, the French Ambassador in Colombia, Boinet Lecompte, to the Ministry).

26. Since the beginning of the Conference, the head of the Chilean delegation stated that, in the case the world ended up divided in two, the American republics should choose the "democratic" field. But he also remarked that the Inter-American system should become, in case of blockage of the UN System, an alternative for the region (FRUS, 1948, vol. 9: 24-25).

27. FNA. Archives du Ministère de l'Intérieur. F1a, box 3469. Administrative Act (Arrêté) of 14/06/48.

28. That time also saw the creation of other institutions with the same general purpose as the Maison de l'Amérique latine 
(1945), the Chambre de Commerce France-Amérique latine (1946), the Groupe parlementaire d'amitié France-Amérique latine (1947) and the Institut des Hautes Etudes de l'Amérique latine (1953) (Chonchol, Jacques and Martinière, Guy (1985): 113-114).

29. FMFADA. Série Nations Unies et Organisations Internationales 1944-1959, vol. 104. S.10.11. Note of 12/10/51, of Direction Amérique of the French Ministry of Foreign Affairs on the French participation in the American organizations.

30. FMFADA. Série B Amérique 1944-1952, sub-série Questions générales, Union latine, vol. 76. Pierre Cabanes' press conference, [1948]. Congrès International De L'Union Latine. (1954a). Anais do 1 Congresso da União Latina: realizado no Rio de Janeiro de 14 à 19 de outubro de 1951. DIN, Rio de Janeiro: 5-6.

31. FMFADA. Série B Amérique 1944-1952, sub-série Généralités, box 125. Secret memorandum of political information A II.O/21.I/4603/517.036/ZACAPA of 16/10/51 from the Service of Foreign Documentation and Counter-Espionage to the Direction Amérique of the French Ministry of Foreign Affairs. Subsérie Questions générales, Union latine, vol. 76. Pierre Cabanes' press conference, [1948].

32. On Fernandes rejections of a «Latin bloc», see: Portuguese Ministry of Foreign Affairs Diplomatic Archives. Arquivos da Embaixada portuguesa em Washington, 1937-1948, box EUA.71. Processo 63, Questões Pan americanas. Telegram n. 387 of 07/08/47, from the Portuguese Ambassador at Washington to the Ministry. See also Moura (1990: 23, 46-63) and Bandeira (1978: 312-313).

33. The LU was then formed by a Secretariat, a Cultural Department, an Economic Department, a Social Work Department, a Committee of Programs and Coordination, and a Law Committee (FMFADA. Série B Amérique 1944-1952, sub-série Questions générales, Union latine, vol. 76. LU Charter, article 8).

34. FMFADA. Série B Amérique 1944-1952, sub-série Questions générales, Union latine, vol. 76. Pierre Cabanes's interview, [1948].

35. Idem.

36. Idem.

37. FMFADA. Série B Amérique 1944-1952, sub-série Questions générales, Union latine, vol. 76. Note of 06/08/49, from the Ministry to the French Ambassadors to Argentina, Uruguay, Brazil and Chile.

38. FMFADA. Série B Amérique 1944-1952, sub-série Questions générales, Union latine, vol. 76. Note n. 1533/RC of 17/12/49, from the French Charge d'Affairs in Argentina to the Direction Générale des Relations Culturelles of the French Foreign Ministry. Telegram n. 664/665 of 18/12/50 from the French ambassador in Argentina, Georges Picot, to the Ministry.

39. FMFADA. Série B Amérique 1944-1952, sub-série Questions générales, Union latine, vol. 76. Rapport of the UL General Secretary on the first Summit: 14

40. Centro de Pesquisa e Documentação Histórica Contemporânea of the Fundação Getulio Vargas, Brazil. Papéis Oswaldo Aranha. OA.22.375.419. Letter of 17/02/44, from Fontoura to Presidente Vargas. See also Rocha (2013).

41. FMFADA. Série B Amérique 1944-1952, sub-série Questions générales, Union latine, vol. 76. Note n. 983/IP of 21/10/50, from the French Ambassador in Portugal to the Ministry.

42. FMFADA. Série Nations Unies et Organisations Internationales 1944-1959, vol. 104. S.10.11. Memorandum of 08/09/47, from the French ambassador in Brazil, Hubert Guerin, to the Ministry. Serie Cabinet du Ministre, sub-série Georges Bidault 19441947, vol. 31. Memorandum n. 838/AM of 29/12/47, of Minister Georges Bidault on the relations between the United States and Latin America

43. At the moment of the first LU Conference of 1951, for instance, Brazil had already turned illegal the Communist Party (CP) and broken off relations with the USSR, but not with Poland nor Czechoslovakia. In Chile, CP had also been prohibited, but in Argentina its legality was maintained and the relations remained open with the USSR. The same for Guatemala's CP. In
Mexico even circulated communist publications subsidized by the State (FMFADA. Serie B Ameriques 1944-1952, sub-série Généralités, vol. 57. Letter n. 83/AM of 18/01/52, from the Direction Amérique of the Ministry of Foreign Affairs to the embassies in Latin America). For a more complete comparative analyzes on this political issues, see Bethell (1994: 189-195).

44. That was, for example, the Brazilian position during the meeting of Ministers of Foreign Affairs of the American States in Washington, in 1951, while the US sought to make the TIAR and the OAS a device to fight against external threats (FRUS 1951, vol. second: 961-965).

45. Other factors should be taken into consideration such as the USSR's Latin American policy, even if there are still few studies on the topic (Pettinà, 2007).

46. At Marshall's request, then Secretary of Defense, the US would claim even a Latin American action outside the framework of the OAS (Marshall to Acheson, 05/03/51 in FRUS, 1951, vol. 2: 1004-1006)

47. Memorandum of the Under-Secretary of State of 20/11/53 on the NSC-144 (FRUS, 1952-1954, vol. 4: 26-43).

48. FMFADA. Série B Amérique 1944-1952, sub-série Questions générales, Union latine, vol. 76. Note n. 983/IP of 21/10/50, from the French ambassador in Portugal to the Ministry.

49. In late 1950, the newly elected president Getulio Vargas declared to the public to give all powers to its future Minister of Foreign Affairs for the development and implementation of a foreign policy directed to Europe and to the United States (National Archives of the UK (NAUK). FO 371/81255. Letter of 15/12/50, from the British Ambassador in Brazil to the Foreign Office).

50. FMFADA. Series B Amérique 1944-1952, subseries Questions générales, Union latine, vol. 76. Letter n. 1049/AM of 21/12/50, from the French Chargé d'Affaires in Brazil to the Ministry. Letter n. 4434/AM of 28/09/51, from the French Ambassador to the United States to the Ministry.

51. Fontoura, J. N. (1950). 'Le premier congrès international de l'Union Latine se tiendra l'an prochain à Rio de Janeiro'. Le Monde, 7th year, n. 1595, 12-13/03/1950: 3 .

52. FMFADA. Series B Amérique 1944-1952, sub-series Questions générales, Union latine, vol. 76. Letter n. 32/AM of 17/09/50, from the French Embassy in Brazil to the Ministry.

53. FMFADA. Series B Amérique 1944-1952, sub-series Questions générales, Union latine, vol. 76. Personal letter of 25/09/50, from the French Ambassador in Brazil to Georges Bidault.

54. The Spanish Foreign Minister, Martin-Artajo, had already stated that he saw the idea of a Latin Bloc as a way for France to gain influence over Latin America to the detriment of Madrid (Spanish Ministry of Foreign Affairs Diplomatic Archives. R $1374 / 10$. Notes from the Minister [1945-1946] for press interview).

55. Argentina, Belgium, Bolivia, Brazil, Chile, Colombia, Costa Rica, Cuba, Dominican Republic, El Salvador, Ecuador, Spain, France, Guatemala, Haiti, Honduras, Italy, Mexico, Nicaragua, Panama, Paraguay, Peru, Portugal, Romania, Uruguay and Venezuela. (Congrès International De L'Union Latine. (1954): 159-165).

56. Congrès International De L'Union Latine. (1954a): 37-38, 4243, 60-63, 69-70, 127-138.

57. FMFADA. Series B Amérique 1944-1952. Sub-Series Questions générales, Union latine, vol. 76. Letter n. 894/AM of 27/10/51, from the French Ambassador to Brazil to the Ministry. Sub-series Généralités, vol. 125. Secret memorandum of policy information A/II.O/21.I/4603/517.036/ZACAPA of 16/10/51, from the Foreign Service Documentation and Counter-Espionage to the Direction Amérique of the French Ministry of Foreign Affairs.

58. Idem.

59. Congrès International De L’Union Latine. (1954a): 44.

60. FMFADA. Series B Amérique 1944-1952. Sub-Series Questions générales, Union Latine, vol. 76. Letter n. 1387/AM of $11 / 06 / 51$, from the French Ambassador in Spain to the Ministry. 
61. Among the decisions there were, for example, the "moral" support to the sale of books, the promotion of cultural encounters and even the opening of "university" theaters (Congrès International De L'Union Latine. (1954): 171). About the clash of forces, see the interesting report of the British Chargé d'Affaires at Rio in NAUK. FO 371/90425. Letter n. 264 of 07/12/51.

62. FMFADA. Series B Amérique 1944-1952. Sub-Series Questions générales, Union latine, vol. 76. Letter n. 939/AM of 23/11/51 and n. 970 of 07/12/51, from the French Ambassador to Brazil to the Ministry, and note of $08 / 12 / 51$ from Pierre Cabanes to the President.

63. FMFADA. Series Nations Unies et Organisations Internationales 1944-1959, vol. 104. S.10.11. Note of 12/10/51, from the Direction Amérique of the French Ministry of Foreign Affairs on French participation in the American organizations. Chonchol, Jacques and Martinière, Guy (1985): 127-133.

64. Lecture by the Secretary General of the Latin Union entitled «'L'Union Latine, son rôle et ses perspectives» at the Association France-Amérique in Paris on January 20th, 2010. http://www.cybel.fr/html/Communaute/fr-am/200110.pdf (accessed 26/11/13).

\section{REFERENCES}

Aron, Raymond (1962) Paix et guerre entre les nations. CalmannLévy, Paris.

Bandeira, Luiz Alberto M. (1978) Presença dos Estados Unidos no Brasil (Dois séculos de historia). $2^{\mathrm{a}}$ ed. Civilização Brasileira, Rio de Janeiro.

Bethell, Leslie and Roxborough, Ian (1992) Latin America between the Second World War and the Cold War, 1944-1948. Cambridge UP, Cambridge.

Bethell, Leslie (org.) (1994) The Cambridge History of Latin America. Vol. VI, parte 2. Cambridge UP, Cambridge.

Bozo, Frederic; Rey, Marie-Pierre; Ludlow, Piers N. and Nuti, Leopoldo (2008) Europe and the End of the Cold War: A Reappraisal. Routledge, New York.

Braillard, Philippe (1987) Mythe et réalité du non-alignement. PUF, Paris

Campbell, Thomas M. and Herring, George C. (eds.) (1975) The Diaries of Edward R. Stettinius, Jr., 1943-1946. New Viewpoints, New York

Centro de História e Documentação Diplomática (2002) O Brasil e as origens da União Latina. CHDD/FUNAG, Brasília.

Cervo, Amado L. (2007) Relações Internacionais da América Latina: velhos e novos paradigmas. Saraiva, São Paulo.

Chonchol, Jacques and Martinière, Guy (1985) L'Amérique latine et le latino-américanisme en France. L'Harmattan, Paris.

Congrès International De L'Union Latine (1954a) Anais do 1 Congresso da União Latina: realizado no Rio de Janeiro de 14 à 19 de outubro de 1951. DIN, Rio de Janeiro.

Congrès International De L'Union Latine (1954b) Guide. Union latine, 2 Congrès international. Union latine, Madrid.

Congrès International De L'Union Latine (1956) Procès-verbaux du 2 Congrès international de l'Union latine tenu à Madrid, mai 1954. Secrétariat général de l'Union latine, Madrid.

Farias, Rogério S. (2014) "Brazil and the Origins of the Multilateral Trading System". The International History Review. doi: 10.1080/07075332.2014.897248
Fontoura, João N. (1963) Memorias. A Aliança Liberal e a Revolução de 1930, Vol. II. Globo, Rio de Janeiro.

Grandin, Greg and Joseph, Gilbert (org.) (2010) A Century of Revolution. Insurgent and Counterinsurgent Violence During Latin America's Long Cold War. Duke UP, Durham.

Grosser, Alfred (1989) Affaires Extérieure. La politique de la France 1944-1989. Flammarion, Paris.

Harmer, Tanya and Segovia, Alfredo R. (eds.) (2014) Chile y la Guerra Fría global. RIL Editores, Santiago.

Harmer, Tanya (2014) "The Cold War in Latin America". In The Routledge Handbook of the Cold War, Kalinovsky, Artemy M. and Daigle, Craig (eds.). Routledge, Abingdon.

Joseph, Gilbert M. (2008) "What We Now Know and Should Know: Bringing Latin America More Meaningfully into Cold War Studies". In In From the Cold. Latin America's new Encounter with the Cold War, Joseph, Gilbert. M. and Spenser, Daniela (org.). Duke UP, Durham.

Kennedy, Paul. (2006) The Parliament of Man. Random House, New York.

Moura, Gerson (1990) O alinhamento sem recompensa: a politica externa do Governo Dutra. FGV/CPDOC, Rio de Janeiro.

Morgenthau, Hans (1948) Politics Among Nations; the struggle for power and peace. A.A. Knopf, New York.

Pernet, Corinne A. (2014) "Shifting Position to the Global South: Latin America's Initiatives in the Early Years at the United Nations". In Auroi, Claude. and Helg, Aline (eds.), Latin America 1810-2010. Dreams and Legacies. Imperial College Press, London.

Pettinà, Vanni (2007) "Del anticomunismo al antinacionalismo: La presidencia de Eisenhower y el giro autoritário en la América Latina de los años 50". Revista de Indias, LXVII (240): 579-589.

Rabe, Stephen (1988) Eisenhower and Latin America: the foreign policy of anti-communism. UNC Press Books, Chapel Hill.

Redondo Jiménez, Juan Carlos (1996) Franco e Salazar: as relações luso-espanholas durante a guerra fria. Assirio \& Alvim, Lisboa.

Rocha, Alexandre Luis Moreli (2013) “An American Mission: the Appointment of João Neves da Fontoura as New Brazilian Ambassador to Portugal in 1943". Journal of Transatlantic Studies, 11(3): 264-277. doi: 10.1080/14794012.2013.814389

Rollo, Maria Fernanda (1994) Portugal e o Plano Marshall. Editorial Estampa, Lisboa.

Stoetzer, Carlos (1993) The Organisation of American States. Praeger, Westport.

Telo, Antônio José (1996. Portugal e a NATO, o reencontro da tradição atlântica. Cosmos, Lisboa.

Viñas, Ángel (2003) En las garras del aguila. Los pactos con Estados Unidos, de Francisco Franco a Felipe Gonzalez (19451995). Crítica, Barcelona.

Westad, Odd Arne (2005) The Global Cold War. Third World Interventions and the Making of Our Times. Cambridge UP, Cambridge.

Westad, Odd Arne (2010) "The Cold War and the international history of the twentieth century". In The Cambridge History of the Cold War, Vol. I, Leffler, Melvin P. and Westad, Odd A. (org.). Cambridge: Cambridge UP. http://dx.doi.org/10.1017/ CHOL9780521837194.002 